Note

\title{
'AROEIRA-BRANCA' [Lithraea molleoides (Vell.) Engl. - ANACARDIACEAE] SEED QUALITY EVALUATION BY THE X-RAY TEST
}

\author{
Cibele Ferreira Machado; Sílvio Moure Cícero* \\ USP/ESALQ - Depto. de Produção Vegetal, C.P. 9 - 13418-900 - Piracicaba, SP - Brasil. \\ CNPq scholarship. \\ *Corresponding author <smcicero@esalq.usp.br>
}

\begin{abstract}
Aroeira-branca', an arboreal species of great ecological and economic importance, is seed propagated and presents limitations with respect to the availability of methods for seed quality evaluation. The X-ray test has been considered of potential value because it is accurate, quick and nondestructive. In this context, the objective of this work was to verify the possibility of this test to detect damage and/or abnormalities in aroeira-branca embryos, in an attempt to correlate these anomalies to germination. Four seed lots were collected in different locations in the southern region of the State of Minas Gerais, Brazil, during 2001. The $\mathrm{X}$-ray test consisted of submitting $100 \mathrm{seeds} / \mathrm{lot}$ to radiation (exposure of seeds to radiation of $13 \mathrm{kV} / 5$ minutes) and classifying them according to embryo/embryo cavity proportions of $0,<50,50-75$ and $100 \%$, with the latter class divided into normal and abnormal according to embryo morphology. The germination test was then carried out to detect possible relationships between seed anatomy and the resulting seedling/ seed ratio, as revealed by radiographs. Seeds presenting an embryo/embryo cavity proportion lower than $100 \%$, as determined by the X-ray test, did not germinate, and those presenting abnormal embryos produced abnormal seedlings or did not germinate, providing evidence that the X-ray test is effective to assess seed quality.
\end{abstract}

Key words: radiography, embryo morphology, seed germination, forest species

\section{AVALIAÇÃO DA QUALIDADE DE SEMENTES DE AROEIRA- BRANCA [Lithraea molleoides (Vell.) Engl. - ANACARDIACEAE] POR MEIO DE RAIOS-X}

\begin{abstract}
RESUMO: A aroeira-branca, espécie arbórea de grande importância ecológica e econômica, multiplica-se por sementes, as quais têm apresentado limitações quanto à disponibilidade de métodos para a avaliação da qualidade. $\mathrm{O}$ teste de raios-X tem se destacado por ser um método rápido, preciso e não destrutivo. Neste contexto, o presente trabalho foi realizado com o objetivo de verificar a possibilidade de uso do teste de raios-X na detecção de danos e ou anormalidades em embriões de aroeira-branca, bem como associá-los à germinação. Foram utilizados quatro lotes de sementes colhidas em áreas da região sul de Minas Gerais, no ano de 2001. Cem sementes/lote foram submetidas ao teste de raios-X, que consistiu na radiografia (condições de exposição à radiação: $13 \mathrm{kV} /$ 5 minutos) e classificação das sementes baseada na proporção do embrião em relação à cavidade embrionária, de $0,<50,50-75$ e 100\%, sendo a última classe dividida quanto à morfologia do embrião, em normal e anormal. Em seguida, foi conduzido o teste de germinação, visando detectar possíveis correspondências entre a anatomia das sementes e as respectivas plântulas/sementes resultantes. As sementes em que a proporção embrião/cavidade embrionária foi inferior a $100 \%$ não germinaram, e aquelas pertencentes à classe radiográfica de embriões morfologicamente anormais resultaram em plântulas anormais ou sementes não germinadas, evidenciando a eficiência da técnica de raios-X para avaliar a qualidade das sementes.

Palavras-chave: radiografia, morfologia de embrião, germinação de semente, espécie florestal
\end{abstract}

\section{INTRODUCTION}

The X-ray test, introduced by Simak \& Gustafsson (1953) to assess seed quality of some conifers, within the scope of seed technology, consists of the radiographic analysis of internal seed structures and is, at present, utilized for several purposes. When a beam of X-rays passes through seeds, a permanent image of them is formed on a film. The images can present a higher or lower degree of radiopacity (light) and radioluminescence (dark) depending on the absorption level of X-rays by the seeds, which is determined by factors 
such as composition, thickness and density of the tissues, and wavelength of the ionizing radiation (Simak, 1980; International Seed Testing Association, 1993).

Even though X-rays are potentially harmful to seeds, the low rate that is absorbed during the test is not sufficient to induce genetic mutations and does not affect their germination (Simak \& Gustafsson, 1953; Swaminathan \& Kamra, 1961; Chavagnat \& Le Lezec, 1985; Bino et al., 1993). In addition, it is a test that does not require previous seed treatment, with the advantages of being nondestructive, quick and easy-toperform.

Seed radiography allows the visualization of mechanic injury, damage caused by insects or other caused by pre and post-harvest adverse factors, in the form of cracks or fractures (Simak, 1980; ISTA, 1993; Poulsen et al., 1998). In addition, it allows detection of abnormalities in embryos, and to determine their development stage (Simak \& Gustafsson, 1953; Simak, 1980).

In seed quality control programs of forest (Simak, 1980) and olericultural (Chavagnat, 1987) species the Xray test is routinely utilized. Since morphological aspects of the seeds, possibly associated to viability, can be assessed through the X-ray test (Copeland \& McDonald, 1985), many scientists have sought to establish a relationship between seed anatomy and germination or seedling morphology; such correspondence varies according to species (Simak, 1991).

The application of this technique is particularly promising in the analysis of seeds of aroeira-branca, an arboreal species of economic expression and ecological importance, with propagation units being drupe-type fruits, makes the exam of the embryo by other methods impracticable. In addition, the species exhibits a prolonged seed germination period, thus demanding quick tests for quality evaluation. Within this context, the objective of the present work was to evaluate the possibility of using the X-ray test for the detection of damage and/or abnormalities in aroeira-branca embryos, and assessing their effects on germination.

\section{MATERIAL AND METHODS}

Fruits were harvested in January 2001, in distinct areas where the species occurs naturally, of the southern region of the State of Minas Gerais $\left(21^{\circ} 04^{\prime}-21^{\circ} 14^{\prime} \mathrm{S}\right.$, $45^{\circ} 02^{\prime}-45^{\circ} 12^{\prime} \mathrm{W}$ ), at the municipal districts of Ijaci (lot 1), Lavras (lots 2 and 3) and Ribeirão Vermelho (lot 4). After harvest, fruits were submitted to manual friction in a sieve under running water for epicarp removal and then dried. Fruits processed in this way were hereafter called 'seeds'. During the experimental period seeds remained wrapped in paper packaging in an incubator adjusted to $19 \pm 1^{\circ} \mathrm{C}$ and $50 \pm 8 \% \mathrm{RH}$.
One hundred seed per lots were utilized for the X-ray test, distributed on a plexiglass plate with individualized cells. During to exposition radiation, plates were placed over radiographic films (Kodak, Min-R 2000, size $18 \times 24 \mathrm{~cm}$ ), positioned $35 \mathrm{~cm}$ from the radiation-emitting source, by utilizing a Hewlett-Packard (model MX20) Faxitron X-ray device, adjusted to $13 \mathrm{kV}$ and exposure time of 5 minutes. These exposure conditions were determined in previous assays.

Radiographic films were developed in an automatic processor (Hope X-Ray, 319 micro-Max and the radiographic images digitized in scanner (Umax, Power Look 1100 model), for later seed evaluation by a computer program. The radiographic analysis of the seeds was based on the different stages of embryo development, established according to the proportion of the embryo cavity occupied by the embryo, of $0,<50,50-75$ and $100 \%$. Seeds showing an embryo/embryo cavity ratio of $100 \%$ were further divided into classes as normal and abnormal, according to embryo morphology. Intact embryos, i.e., those that were complete and showing developed structures, and those having limited damage (with more than $50 \%$ of functional cotyledons), were considered as normal; no damage present in the embryo axis was allowed. Mature aroeira-branca seeds present a poorly developed plumule, which is macroscopically invisible (Figure 1c) and therefore not discernible on the radiograph. The utilized terminology, as well as seed classification, are based on those described by Simak \& Gustafsson (1953) and Simak (1980) for exalbuminous seeds of forest species.

Seeds were submitted to the germination test, and the identity of each seed was tracked, to verify possible associations between seed anatomy and the resulting/corresponding seedlings or non-germinated seeds.

Tests were conducted at $27^{\circ} \mathrm{C}$ with 8 hours of light/day. Seeds were previously and individually disinfested by immersion in a sodium hypochlorite solution (2\%), for 3 minutes, and then washed with distilled water and distributed among plastics gerboxes (16 seeds/box) over a $2 \mathrm{~cm}$ layer of vermiculite $(0.6-1.2 \mathrm{~mm}$ $\varnothing)$ previously moistened with distilled water $(60 \%$ of the retention capacity). Substrates were maintained moist during the entire test period. Assessments were performed daily for a period of 45 days after test installation. The produced seedlings, as well as seeds that did not germinate during the period of time planned for the test, were documented photographically with a digital camera.

Seed moisture content was determined prior to the onset of the experiment, by the incubator method at $105 \pm 3^{\circ} \mathrm{C} / 24$ hours (Brasil, 1992). The results, expressed as percentages, were calculated on a wet weight basis $(\mathrm{Wb})$. 


\section{RESULTS AND DISCUSSION}

Seeds of the four lots had moisture contents around $10 \%$ at experiment installation. Based on illustrations of the mature aroeira-branca embryos and seeds (Figure 1a-b). The radiographic images of seeds allowed an appropriate visualization of their internal structures (Figures 2 and 3). Therefore, the radiographic analysis allowed seeds to be classified based on their development stage and embryo morphology.

The morphological abnormality patterns in aroeira-branca embryos, verified on the radiographs, were basically the following: damage occupying more than $50 \%$ of the cotyledons (Figure $3 \mathrm{e}$ ) and/or occurring in the hypocotyl-radicle axis (Figure 3d); deformations or morphological disorders, radiographically characterized by irregular conformation (Figure 3f). The frequencies in the stages of embryo development identified in the four lots, as well as in the classes of embryo morphology considered as normal and abnormal, are shown in Table 1.

The array of light and dark shades observed in radiographic images of seeds is defined as a function of the level of absorption of X-rays in distinct regions of the seed, which is determined by the thickness, density and composition of the tissues (Simak, 1980; ISTA, 1993). Since aroeira-branca seeds devoid of embryonic tissues

Table 1 - Percentages of aroeira-branca seeds, by lot, observed in classes determined by the X-ray test.

\begin{tabular}{cccccc}
\hline & \multicolumn{5}{c}{ Embryo/embryo cavity ratio } \\
\cline { 2 - 5 } Lot & \multirow{2}{*}{0} & $<50$ & $50-75$ & \multicolumn{2}{c}{100} \\
\cline { 4 - 5 } \cline { 3 - 5 } & & & & Normal & Abnormal \\
\hline 1 & 10 & 2 & 3 & 78 & 7 \\
\hline 2 & 1 & 1 & 0 & 82 & 16 \\
3 & 9 & 5 & 4 & 69 & 13 \\
4 & 6 & 3 & 0 & 87 & 4 \\
\hline
\end{tabular}

do not offer resistance to the penetration of X-rays, the resulting images are radiolucent (dark) (Figure 3a); the only observed constituents correspond to resin canals present in the fruit mesocarp, and the seed integument. On the other hand, seeds for which the embryo/embryo cavity ratio is $100 \%$ are highly resistant to the passage of X-rays, having therefore radiopaque images (light) (Figure 2a).

Seed radiography can be of help to evaluate seed viability (Swaminathan \& Kamra, 1961; Copeland \& McDonald, 1985). Therefore, it is necessary to establish a relationship between the internal structures of the seeds and the corresponding seedlings that are produced, as demonstrated in the present work.

Results obtained by the germination test correspond to the expected germination based on the classes obtained with the radiography of the seeds (Table 2). The germination test revealed that seeds in which the embryo did not present good contact with the internal surface of the integument along all its extension were not viable, since all seeds showing an embryo/embryo cavity ratio lower than $100 \%$ invariably did not germinate.

Variations of embryos during the development stage, observed for the aroeira-branca seed samples, frequently occurs in forest species, certainly resulting from disuniform flowering. Consequently, during harvest the trees bear seeds at different maturity stages, when the occurrence of morphologically immature embryos can be verified. Such fact helped the development of the X-ray technique which, before anything else, aims at the establishment of an embryo development stage that is suitable for harvest (Simak \& Gustafsson, 1953).

With regard to the morphological profile of developed embryos (embryo/embryo cavity ratio of $100 \%$ ), it was observed that seeds considered normal by the $\mathrm{X}$ ray test resulted in normal and abnormal seedlings and non-germinated seeds (Table 2). However, the percent-

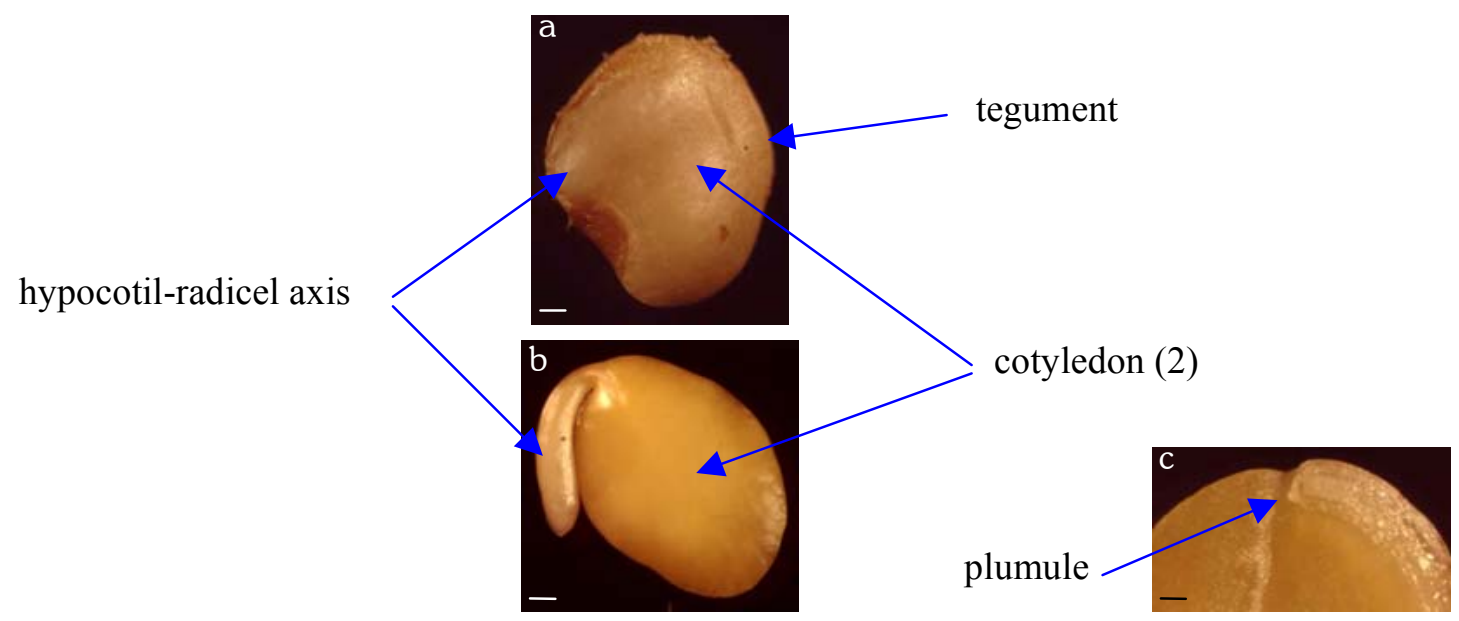

Figure 1 - Aroeira-branca mature seed: (a) external aspect; (b) embryo; (c) portion of embryo, longitudinally sectioned, showing plumule. Scale bar (a-b) $=4.5 \times 10^{-4} \mathrm{~m}$; scale bar (c) $2.2 \times 10^{-4} \mathrm{~m}$. 
Table 2 - Normal seedlings (NS), abnormal seedlings (AS) and non-germinated seeds (NGS), expressed as percentages, obtained by the germination test of four lots of aroeira-branca seeds, for each class determined in the X-ray test.

\begin{tabular}{|c|c|c|c|c|c|c|c|}
\hline \multirow{3}{*}{ Lot } & \multirow[b]{3}{*}{ Category } & \multicolumn{6}{|c|}{ Embryo/embryo cavity ratio } \\
\hline & & \multirow{2}{*}{0} & \multirow{2}{*}{$<50$} & \multirow{2}{*}{$50-75$} & \multicolumn{2}{|c|}{100} & \multirow{2}{*}{ Total } \\
\hline & & & & & Normal & Abnormal & \\
\hline & & --- & ---- & $--\%$ & $-\ldots \ldots$ & 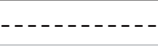 & \\
\hline \multirow[t]{3}{*}{1} & NS & 0 & 0 & 0 & 61 & 0 & 61 \\
\hline & AS & 0 & 0 & 0 & 1 & 0 & 1 \\
\hline & NGS & 10 & 2 & 3 & 16 & 7 & 38 \\
\hline \multirow[t]{3}{*}{2} & NS & 0 & 0 & 0 & 78 & 0 & 78 \\
\hline & AS & 0 & 0 & 0 & 2 & 13 & 15 \\
\hline & NGS & 1 & 1 & 0 & 2 & 3 & 7 \\
\hline \multirow[t]{3}{*}{3} & NS & 0 & 0 & 0 & 64 & 0 & 64 \\
\hline & AS & 0 & 0 & 0 & 1 & 1 & 2 \\
\hline & NGS & 9 & 5 & 4 & 4 & 12 & 34 \\
\hline \multirow[t]{3}{*}{4} & NS & 0 & 0 & 0 & 78 & 0 & 78 \\
\hline & AS & 0 & 0 & 0 & 2 & 0 & 2 \\
\hline & NGS & 6 & 3 & 0 & 7 & 4 & 20 \\
\hline
\end{tabular}

(a)

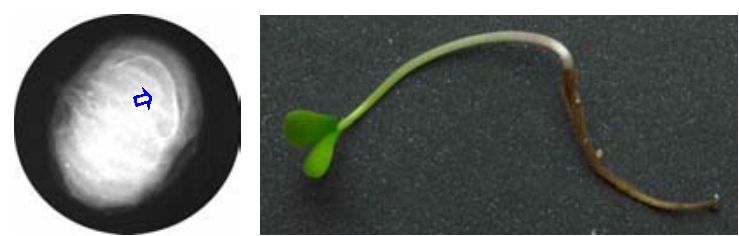

(b)
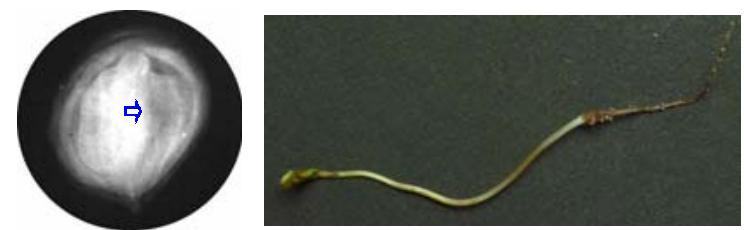

(c)
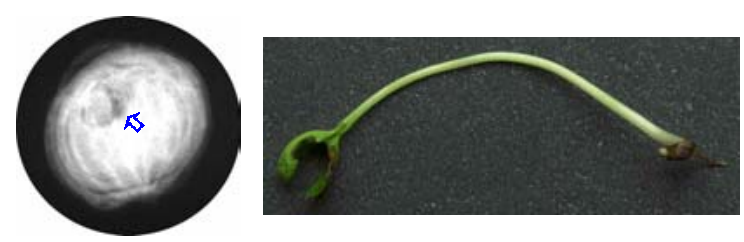

Figure 2 - Radiographic images of aroeira-branca seeds with respective resulting seedlings: (a) morphologically normal embryo and normal seedling (arrow indicates embryo axis); (b) morphologically abnormal ambryo and abnormal seedlings (arrow indicates abnormality); (c) embryo damaged at cotyledons and axis, and adnormal seedling (arrow indicates damage).

age of normal seedlings of each lot, in this class, was: $78.21 \%$ (lot 1 ); $95.12 \%$ (lot 2); 92.75\% (lot 3); $89.66 \%$ (lot 4), indicating a good correspondence among them.

During the germination test seeds remain exposed to factors that compete for the reduction of the germination potential, such as the action of microorganisms that might come along with them, and the presence of anatomically normal wrapped in paper packaging which are
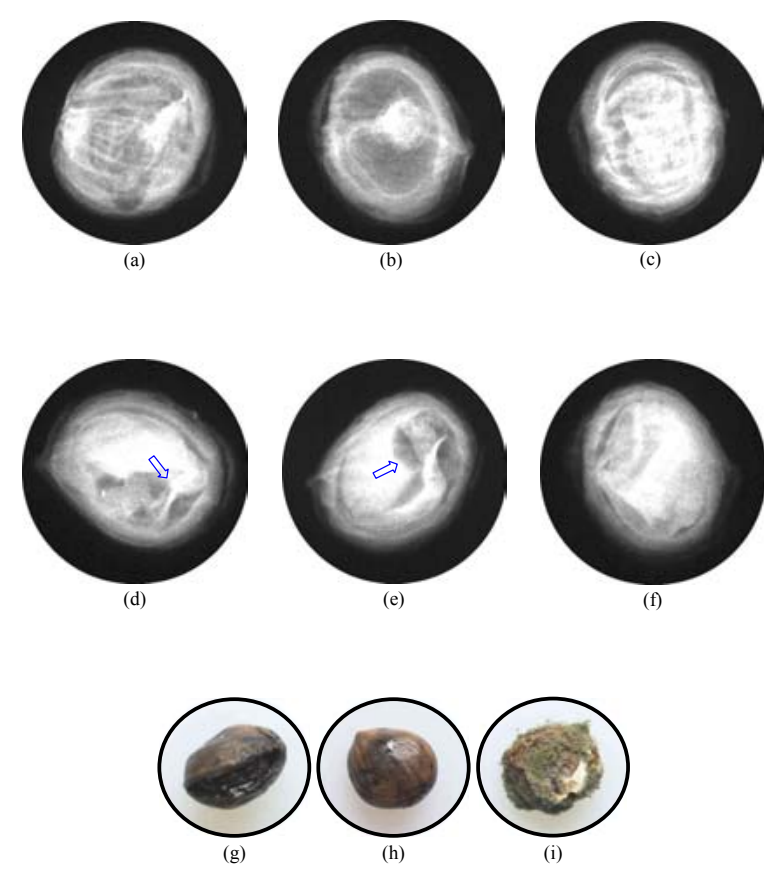

Figure 3 - Radiographic images of aroeira-branca seeds: embryo/ embryo cavity ratio of $0 \%(a),<50 \%$ (b) and $50-75 \%$ (c); embryos with damaged axis (d), with more than $50 \%$ of cotyledons damaged (e), and deformed (f). Fruit aspect in seeds of aroeira-branca, non-germinated in germination test, belonging to classes ' $a$ ' to ' $\mathrm{f}$ ' (g-i).

dead by natural causes or which are at more advanced deterioration stages (Swaminathan \& Kamra, 1961; Van der Burg et al., 1994).

Within this context, making inferences about seed quality based on a radiographic exam might be questionable. Seeds corresponding to morphologically abnormal embryo classes, as determined in the X-ray test, only gave origin to abnormal seedlings and non-germinated seeds 
(Table 2), of which some were unquestionably dead, as evidenced by the aspect observed when fruits were opened (Figure $3 \mathrm{~g}$ ). Embryos in this class belonging to lots 1 and 4 did not germinate, whereas in lot 3 germination of one seed with a damaged axis was not prevented, but resulted in the formation of an abnormal seedling (Figure 2c). Lot 2 in turn had a considerable number of abnormal seedlings, originated from embryos bearing a characteristic morphological disorder (Figure 2b). These seedlings also manifested the same pattern of abnormality, i.e., seedlings showing deformations and hard tissues. In this specific case, embryo morphology was related to the morphology of the corresponding seedlings originated in the germination test.

The X-ray technique is efficient for the detection of damages and abnormalities in aroeira-branca embryos, detrimental to germination. Discarding damaged or abnormal seeds, as shown in this study, can improve the germination performance of seed lots. This procedure, when carried out before sowing, is more adequate for use with perennial plants such as forest species.

\section{REFERENCES}

BINO, R.J.; AARTSE, J.W.; VAN DER BURG, W.J. Non-destructive Xray analysis of Arabidopsis embryo mutants. Seed Science Research, v.3, p.167-170, 1993.
BRASIL. Ministério da Agricultura e Reforma Agrária. Regras para análise de sementes. Brasília: CLAV; DNDV; SNAD; MA, 1992. 365p.

CHAVAGNAT, A. Use of soft X-ray radiography for studying seed quality in horticulture. Acta Horticulturae, n.215, p.153-158, 1987.

CHAVAGNAT, A.; LE LEZEC, M. Détermination de la valeur culturale des semences par la radiographie industrielle aux rayons X. Application aux pépins de pommier (Malus pumila Mill.). Agronomie, v.5, p.187$192,1985$.

COPELAND, L.O.; McDONALD, M.B. Principles of seed science and technology. 2.ed. New York: Macmillan, 1985. 321p.

INTERNATIONAL SEED TESTING ASSOCIATION. ISTA. International rules for seed testing. Seed Science and Technology, v.21, 1993.363p. Supplement.

POULSEN, K.M.; PARRATT, M.J.; GOSLING, P.G. (Ed.) Tropical and sub-tropical tree and shrub seed handbook. Zürich: ISTA, 1998. 204p.

SIMAK, M. Testing of forest tree and shrub seeds by X-radiography. In: GORDON, A.G.; GOSLING, P.G.; WANG, B.S.P. (Ed.) Tree and shrub seed handbook. Zürich: ISTA, 1991. p.14-1; 14-28.

SIMAK, M. X-Radiography in research and testing of forest tree seeds. Report SUAS Department of Silviculture, n.3, p.1-34, 1980.

SIMAK, M.; GUSTAFSSON, Å. X-Ray photography and sensitivity in forest tree species. Hereditas, v.39, p.458-468, 1953.

SWAMINATHAN, M.S.; KAMRA, S.K. X-Ray analysis of the anatomy and viability of seeds of some economic plants. Indian Journal of Genetics and Plant Breeding, v.21, p.129-135, 1961

VAN DER BURG, W.J.; AARTSE, J.W.; VAN ZWOL, R.A.; BINO, R.J. Predicting tomato seedling morphology by X-ray analysis of seeds. Journal of the American Society for Horticultural Science, v.119, p.258-263, 1994.

$\overline{\text { Received May 17, }} 2002$ 